\title{
Between Censorship and Amnesia: The End of The Penal Colony in French Guiana
}

Entre censure et amnésie : la fin du bagne en Guyane

Charles Forsdick

\section{(2) OpenEdition \\ Journals}

\section{Electronic version}

URL: http://journals.openedition.org/transtexts/1503

DOI: 10.4000/transtexts. 1503

ISSN: 2105-2549

Publisher

Gregory B. Lee

\section{Electronic reference}

Charles Forsdick, "Between Censorship and Amnesia: The End of The Penal Colony in French Guiana", Transtext(e)s Transcultures 跨文本跨文化 [Online], 15 | 2020, Online since 14 December 2020,

connection on 26 January 2021. URL: http://journals.openedition.org/transtexts/1503 ; DOI: https:// doi.org/10.4000/transtexts. 1503

This text was automatically generated on 26 January 2021.

(C) Tous droits réservés 


\title{
Between Censorship and Amnesia: The End of The Penal Colony in French Guiana
}

\author{
Entre censure et amnésie : la fin du bagne en Guyane
}

\author{
Charles Forsdick
}

1 Literature serves as an immediate, spontaneous response to historical change, and can become a privileged site at which sense is made of that change as it occurs. Part of the singularity of the literary text is rooted in its poetics, and its deployment of form and discourse in ways that capture and even harness the dynamic circumstances of the end of empire. Poetry, fiction and other genres often represent the dilemmas and ambiguities of the decolonial tipping point, providing a trace of the struggles physical, intellectual and emotional - that such a transition implies. The literatures of decolonization reflect in this way a symbiotic relationship between the poetic and the political, and the threatening, deeply effective power of the literary work is reflected in numerous cases of book banning, i.e., direct and visible censorship, as colonial authorities sought to control the circulation of ideas deemed seditious: Léon-Gontran Damas's searing account of the threatened collapse of colonial governance in French Guiana in Retour de Guyane (1937) was purchased or seized by the French authorities and then burnt to prevent its circulation; in 1939, Damas's poetry collection Pigments was similarly censored in metropolitan France for "atteinte à la sûreté intérieure de l'État"; the French-Algerian journalist Henri Alleg's memoir La Question (1958), an account of his arrest and torture during the Algerian War of Independence, was banned after its publication when the work's impact on debates about decolonization became clear (although so many copies were by then in circulation that such a move was ineffective); and Mongo Beti's essay Main basse sur le Cameroun: autopsie d'une décolonisation critically dissects, as its evocative subtitle suggests, not only the post-independence government in Cameroon, but also French neo-colonial interventions in the wake of empire - Beti's book was banned in France as well as in his own country after its publication 1971 and only circulated after the author's successful legal challenge in 1976. 
2 These few examples illustrate how censorship provides a clear illustration of the active place of literature in decolonization processes, not only because it demonstrates the perception, not least on the part of the colonial authorities, of the power of the written word, but also because the banning of books was rarely effective and may even be seen as largely counterproductive given the visibility - and often mythical status - it tends to grant to works supposedly withdrawn from circulation. Such examples reveal, therefore, a number of aspects of the role of literature at the moment of decolonization, suggesting that the privileged status of the literary text relates not only to the spontaneity of witnessing, documenting, representing and otherwise processing events as they occur, but also to its potential to act as a trigger for historical change. Literature - in its original form, in translation or other forms of adaptation - has the potential to conceptualize, vocalize and valorize anti-colonial struggle, to create transcolonial networks of communication and solidarity, and to underline the inevitability of the end of empire. It creates connections between situations of struggle otherwise seen as discrete and even distinctive, but also has the power to document the end of empire as it occurs.

3 Taking as its focal point Léon-Gontran Damas's Retour de Guyane, this article explores questions about the dynamics of censorship and amnesia in representations of the Guianese penal colony as that institution came to an end. Its wider aim is to consider the crafting of accounts of the penal institution during the century of its functioning, and the processes of direct and indirect censorship and self-censorship on which these depend. The study examines the entanglement of narratives of judicial punishment and colonial expansionism, exploring the troubled role of questions of race and ethnicity in representations of the bagne. It concludes by focusing on the place of the penal colony and its afterlives in the contemporary cultural and political imaginary, noting in particular the selective amnesia (or indirect censorship) to which the institution is still subject.

4 The context of Damas's Retour de Guyane is that of the decline of the penal colony as an integral, structural element of the colony of French Guiana. Established in 1852, the South American bagne was abolished definitively in 1938, in an interwar context of penal reform, having already ceased to function in New Caledonia over three decades previously (in 1897). The penal colony nevertheless retains a contested status in the postcolonial French-speaking world. Meanings and memories of the institution are fragmented not only according to the scattered locations in which the vestiges of penal heritage sites are now located, but also in the light of the multiple groups with which they have been (and currently still are) associated. In addition, the local circumstances in which the institution is to be understood are regulated by particular political, economic and social issues. Specific contexts have impacted heavily on ways in which the bagne has been remembered or forgotten, has been preserved or has been subjected to processes of postcolonial neglect and ruination. Despite the recent efforts of scholars such as Ann Laura Stoler to integrate the penal colonies into wider patterns of oppression and incarceration, and of historians such as Clare Anderson and Hamish Maxwell-Stewart to elaborate a more transnational and even global history of the institution, the bagne remains marginalized in discussions of postcolonial memory and of the lieux de mémoire [sites of memory] (or more aptly lieux d'oubli [sites of forgetting]) with which it is associated. ${ }^{1}$ 
5 In order to grasp how and where the bagne is situated in contemporary postcolonial literature and memory, there is an initial need to understand the history of the institution. The penal colony represents one of numerous waves of colonial development and of progressive geographical marginalization, as sites of incarceration and hard labour originally situated in France itself were slowly displaced towards a non-European periphery. This shift away from a metropolitan location fulfilled multiple functions: it permitted those considered socially or politically undesirable to be sent elsewhere, beyond France; it contributed to active political and commercial attempts at settlement and colonization of overseas territories in the context of the post-revolutionary colonial empire; and crucially, it provided the workforce required to construct, develop and maintain the infrastructure sustaining such expansion.

6 The ruins and other traces of the bagne in former French colonies have not yet lent themselves to the forms of consensus evident in their Australian equivalents, included on the UNESCO World Heritage List in 2010. Indeed, the bagnes in France's former colonies continue to evolve as sites that encapsulate various strands of postcolonial conflict and contestation. The French had instituted systems of political exile in North Africa and French Guiana during the revolutionary period, but it was not until the beginning of the Second Empire that Louis-Napoléon Bonaparte established a penal establishment in the latter in 1852, with the initial aim of detaining his political opponents. The colony rapidly began to receive convicts following the 1854 decree relating to forced labour. ${ }^{2}$ Central to this decree was the principle of doublage or double peine, meaning that those condemned to a sentence of fewer than eight years were obliged to spend a supplementary period in the colony equivalent to their initial period of incarceration, and that those with longer sentences were transported for life. The conditions in French Guiana were poor, for bagnards and officials alike, and the mortality rate as a result high. The transport of convicts there was suspended in 1867, with prisoners sent to the supposedly less harsh conditions of New Caledonia in Melanesia between 1863 and 1897. Transportés from the French colonies (especially Algerians) continued nevertheless to be sent to French Guiana throughout this period. ${ }^{3}$ From 1887, French convicts with sentences longer than eight years were once again sent there, alongside a new category of convict, the relégué, often guilty of relatively minor (but repeated) crimes and subject to the harshest treatment in the penal colony.

7 As Damas's account illustrates, French Guiana continued to serve as a penal colony well into the twentieth century. Among those it received across the century during which it functioned were also prisoners from elsewhere within the French Caribbean (known as réclusionnaires coloniaux), as well as political activists from Indochina who were deported in the interwar period. ${ }^{4}$ Transportation was abolished in 1938, relegation in 1945, and the last group of French convicts (former and current) returned to Marseilles in 1953. (Although rarely noted, Indochinese prisoners remained after this date, with the final ones not being repatriated until 1963.) The afterlives of the bagne now form an increasingly evident part of French Guiana's complex Creole heritage, reflecting the cross-cultural hybridization (including European elements) that underpins the region's history and culture. ${ }^{5}$ Literature and popular culture have played a key role in sustaining the visibility of the prison colony, both in France and overseas, and in creating specific and often (despite its overtly hybrid history) singularized meanings of it. ${ }^{6}$ In other work, I have explored the contested status of the penal colony as a postcolonial lieu de mémoire in the French-speaking world. ${ }^{7}$ It is clear that the Guianese 
penal colony has entered popular culture through a series of re-figurings that have generated a significant memorial capital relating to the sites: these range from naval officer Frédéric Bouyer's travel narrative La Guyane française: notes et souvenirs d'un voyage exécuté en 1862-1863 (1867) to Henri Charrière's Papillon (1969; popularized internationally in a film version made by James Franklin Schaffner in 1973; the film was remade by Michael Noer in 2017), passing via Albert Londres's 1923 reportage Au bagne (a text often credited with reforming the institution) and a whole cluster of other texts, of various degrees of sensationalism, produced in the interwar period and in the context of which Damas's work is to be understood .

8 French Guiana long featured in earlier travel narratives, as a key text such as Bouyer's La Guyane française (1867) makes very clear. The author demonstrates the way in which, from the time of its establishment, the prison served as an unavoidable point of reference in travelogues devoted to the country from the mid-nineteenth century. From the moment of the traveller's arrival, the colony is defined in terms of its associations with expatriation and deportation:

Me voilà donc à la Guyane, en ce pays dont le décret du 8 avril 1852 a fait la terre d'expatriation des déportés de toute catégorie; réservoir dans lequel la France écoule toute sa lie; colonie privilégiée au profit de laquelle la mère patrie se débarrasse non-seulement de l'écume de ses prisons et de ses bagnes, mais encore de tous ceux qui, à quelque titre que ce soit, sont pour elle un sujet de gêne ou de crainte, une menace pour l'avenir ou une difficulté pour le présent. ${ }^{8}$

In an act of self-censorship, Bouyer claims that professional sensitivity prevents him from reflecting on the relationship between the prison and the future of the colony, but in a parallel example of captatio benvolentiae - a staple device in the travelogue - with which the narrative begins, the author already recognizes the temptation of sensationalism, and seeks to negotiate it:

[J]'espère pouvoir trouver encore à la surface d'un pays vierge, où la nature est si riche et si bizarre, quelques sujets de récits intéressants et neufs. Et si, par hasard, l'histoire de la transportation se présente sous ma plume, illustrée de ses drames lugubres et sanglants, dont le bruit a passé la mer, je tâcherai de concentrer la morale de mes faits divers dans la sphère exclusive des intérêts de la société coloniale. ${ }^{9}$

10 The frontispiece of the volume is nevertheless a lurid engraving illustrating the trope of "forçats cannibals". This is a subject to which Bouyer also devotes an entire chapter towards the end of the book, where he indulges in those same narrative excesses that he claimed to refuse at the opening of the text: "Que de drames sanglants inconnus des hommes se sont accomplis ainsi sous l'œil de Dieu, dans ces déserts de feuillage, à l'ombre de ces arbres séculaires!"10

11 The representation of the bagne by Bouyer remains, therefore, a profoundly contradictory one, setting the tone for subsequent accounts, not least because any critical account of the penal system - as Damas subsequently makes clear - might have been seen to constitute a critique of the colonizing impulse more generally. Negotiating these ideological traps, any dystopian vision of certain transported convicts is complemented by a full acknowledgment of the reformability of others, possible agents of a renewal of the colony, "chez qui la contagion criminelle n'a pas dépassé l'épidémie, et qui peuvent se régénérer par l'expiation". ${ }^{11}$ The result is an active questioning of the representation of the convict:

En France, on n'aperçoit les forçats que de loin, à travers les grilles du bagne, chargés de chaînes, entourés d'argousins, revêtus de la livrée jaune et rouge et 
coiffés du bonnet vert. [...] A la Guyane, on les coudoie chaque jour, leur costume ne diffère guère de celui des autres hommes. [...] On dirait de bons bourgeois voyageant pour leurs affaires ou leurs plaisirs. ${ }^{12}$ complexity of the penal colony during the interwar period, including its global dimensions: the ship which landed the convicts, for instance, previously serviced the Algiers-Marseilles line and now provides transportation between French Guiana and the islands of the Anglophone Caribbean including Trinidad. The context as presented is firmly transcolonial, but the role of the prison in the colonial system is far from evident: "pas une machine à châtiment bien définie, réglée, invariable. C'est une machine à malheur qui travaille sans plan ni matrice". ${ }^{15}$ On entering the forest to observe the construction of a road, this impression is confirmed for Londres: "Ce n'est pas un camp de travailleurs, c'est une cuvette bien cachée dans les forêts de Guyane, où l'on jette des hommes qui n'en remonteront plus." ${ }^{16}$ As his investigation unfolds, Londres is committed to collecting individual and human stories. This accumulation of diverse narratives signals the approach adopted by Londres: ordering what he hears would, in his view, be tantamount to betrayal; the reporter draws the reader into total chaos from which all logic is absent.

One of the principal functions of Londres's reportages was to contribute to public awareness of the penal colony in the interwar period, but they also seek to campaign for an improvement of the conditions of detention. In his writings, the prison appears for what it was: "épouvantable", and ultimately failing to achieve any of its objectives, 
most notably that of providing effective settlers for the mise en valeur of the colony. ${ }^{17}$ When the articles appeared in book form, the author added an open letter to Albert Sarraut, Minister of the Colonies: “Ce n'est pas des réformes qu'il faut en Guyane, c'est un chambardement général", and in September 1924, Londres wrote in Le Petit Parisien that the prison had finally been closed. ${ }^{18}$ This was of course not yet true, but the measures proposed in the letter to Sarraut relating to the separation of convicts according to the severity of their punishment, the treatment of illness, the remuneration of labour and the elimination of double peine had all been accepted. However, it was only after a series other reports (by Louis Roubaud for Le Petit Parisien in 1925, for instance, and by Georges Lefèvre for Le Journal in 1926), after robust campaigning by Salvation Army officer Charles Péan and the political intervention of Gaston Monnerville, that a 1938 decree eventually ordered the formal end of deportation to French Guiana. ${ }^{19}$

Londres's Au bagne may be seen to have triggered a rich corpus of reportages and travelogues on the penal colony, produced in the interwar period. The lawyer Mireille Maroger, who would herself write an account of the penal colony in 1937, was warned against the phenomenon of Londrisme, a term used to describe Londres' particular journalistic style, and it is clear that an appetite for penal reform was complemented and often eclipsed by an emphasis on exoticism and adventure. Travel accounts were supplemented by a number of first-person accounts by former bagnards, as well as exposés on bagnes pour enfants (such as Mettray) in France itself and on the bagnes militaires (or Biribi) in North Africa. ${ }^{20}$ At the same time, a number of more specialist interventions, by doctors and lawyers, were published to satisfy the public appetite, and the bagne featured in Paris in theatrical productions. ${ }^{21}$ International interest grew too, not least in the popular press in the USA.

17 It was in this context of narrative ubiquity of the penal colony that Léon Gontran Damas's travel narrative and ethnographic study Retour de Guyane appeared in 1938. The distinctive - and incendiary - nature of Damas's work relates to the fact that it was one of the first texts to reflect seriously on an aspect absent from most contemporary accounts, i.e., the persistent, self-destructive interdependency of the bagne and the colony in which it was situated. It also actively - as a result of the identity of its author and the emphases of his analysis - inscribes race into discussions of the institution. This is an aspect that Londres had acknowledged (his account made the presence of colonial prisoners, especially from North Africa, apparent), but whose role in the administrative hierarchy of the institution he seemingly suppresses: a reference to the ethnicity of the Afro-Guianese director of the bagne during his visit, Herménégilde Tell, was absent from his initial account in the press and was only inserted when Au bagne appeared in book form. This discrepancy is now presented in the narrative of Tell's life at the museum dedicated to him in Cayenne as an act of censorship or self-censorship, one that provides a further indication of the politically and racially sensitive context in which Retour de Guyane appeared. ${ }^{22}$

Damas's writings have been largely eclipsed by those of the other two authors associated with the emergence of Negritude, Aimé Césaire and Léopold Senghor, whose status as poet-politicians ensured their prominence while they were alive and has served also to consolidate their posthumous reputations. The centrality of poetry to Negritude has, however, led to the privileging of Damas's own poetic output, but Retour de Guyane - a hybrid text, mixing ethnographic report with anti-colonial essay - was 
one of his first works, published the year after his initial poetry collection Pigments. Although details of the censorship of this work are uncertain and depend largely on Damas's own subsequent accounts, it seems clear that the colonial authorities sought to ban Damas's book, allegedly purchasing and burning 1,000 copies of it (of a print-run, at the author's own expense, of only 1,500). The book remains nevertheless a major text in the corpus of literary representations of French Guiana. This is due, in large part, to the fact that Damas's work emphasizes the overlapping histories and intersecting trajectories which characterize his homeland, and which any study of the representation of the bagne must now necessarily take into account.

It is important to note that Retour de Guyane was published in the same year as the abolition of transportation to the penal colony - but it went one step further than other contemporary accounts by actively highlighting the overtly colonial context of the prison, and revealing what its author calls "le problème guyanais dans son intégralité". Damas had travelled to Guiana on behalf of the Musée de l'Homme to study the "hostilité des Marrons et Amérindiens à toute pénétration étrangère" (emphasis in the original), but quickly abandoned this project (although still deposited 120 artefacts in the museum's collections on his return) in order to address instead the paradoxes of the contemporary state of the country: i.e., its condition as "la plus misérable colonie française sur le plus riche territoire du monde...". ${ }^{23}$ Retour de Guyane belongs to a diptych of texts produced by Damas, complemented in this structure by Veillées noires, with these works presenting respectively - in Emmanuel Lézy's terms - "la Guyane du jour" et "la Guyane de la nuit". ${ }^{24}$

20 Damas provides in this text a damning account of French Guiana, the language and vocabulary of which echo in many ways that of nineteenth-century works such as Bouyer's La Guyane française:

[T]erre d'expatriation des déportés de toute catégorie; réservoir dans lequel la France écoule toute sa lie ; colonie privilégiée au profit de laquelle la mère patrie se débarrasse non-seulement de l'écume de ses prisons et de ses bagnes, mais encore de tous ceux qui, à quelque titre que ce soit, sont pour elle un sujet de gêne ou de crainte, une menace pour l'avenir ou une difficulté pour le présent..$^{25}$

21 Retour de Guyane evokes the beginning of the prison system in the mid-nineteenth century and describes the brutality of the tabula rasa imposed on those first transported to the colony:

Trois cents condamnés constituaient le premier convoi. Rien ne fut fait, au préalable, pour recevoir la cargaison. Aucun camp ne fut installé. On répartit les envahisseurs sur les îles qui, bien qu'elles présentassent des avantages certains pour touristes en mal d'exotisme, étaient par trop exiguës et impropres au moindre essai de colonisation. ${ }^{26}$

22 A key element of the rich corpus of texts on the bagne published in the interwar period described above, Retour de Guyane seeks primarily, however, to provide a distinctive and critical account of the institution, suggesting that its failure - which played an integral role in the vicious circle of under-population and under-development in the colony was evident from its mid-nineteenth-century inauguration. In Damas's account of it, the penal colony is to be imagined as a heavily over-determined place - simultaneously heaven and hell, utopia and dystopia. More so than other contemporary reportages (including Londres's Au bagne, the purpose of which was predominantly social rather than political reform), Retour de Guyane seeks also to highlight actively the colonial context of the prison: "tout le problème colonial, français et international", notes 
Damas, "se pose là". ${ }^{27}$ One of the first readers of the text, René Maran (French poet and novelist, and the first Black writer to win the Prix Goncourt in 1921), expressed the distinctiveness of Damas's project, distinguishing it from contemporary French accounts of the colony, the aim of which was "l'illustration du bagne et du bagnard". Maran underlines the ways in which these other, often sensationalist reportages tended to treat the wider Guyanese population as a "quantité parfaitement négligeable". ${ }^{28}$

The tendency of the bagne - and of metropolitan accounts of it - to eclipse other populations and obscure other histories is at the heart of Damas's account, the aim of which is to challenge French perceptions of the colony: "la Guyane c'est le bagne et les Guyanais des fils de bagnard, avec, toutefois, quelques nègres pour l'exotisme". ${ }^{29}$ Damas thus critiques the ways in which the racial assumptions of colonial education have, as elsewhere in the French empire, created racial hierarchies: "Les frères de race de Toussaint-Louverture apprennent à se prosterner devant le vainqueur d'Austerlitz"; and outlines how the presence of the penal colony has failed to disrupt these: "La petite bourgeoisie aime cent fois mieux subir la contamination des forçats que d'admettre la promiscuité dans laquelle vivraient ses rejetons avec ceux de l'arrière-pays". ${ }^{30}$

Retour de Guyane inaugurates in this way a critical reflection on the bagne that developed in the aftermath of its suppression and has arguably culminated in a cluster of postcolonial texts devoted to the institution not only in French Guiana but also in New Caledonia. In this corpus, Damas's work has the peculiarity of being published while the penal colony was still functioning, although he wrote knowing that its abolition was imminent and as a result he engages in the imagination of possible futures for French Guiana. He challenges understandings of the ways in which the penitentiary had contributed to the systematic underdevelopment of the country: "la Guyane continue à vivre son existence de paria... de paria lépreux"; and he reflects on the implications of the collapse of what he categorizes as "un État dans l'État". ${ }^{31}$

In 1938 the end of the prison was thus already inevitable, but Damas directs his attention towards the spectral role of the institution following its abolition and the presence of its afterlives:

Pour préciser, le bagne disparaîtra fatalement de la colonie de la Guyane par l'excès même de ses erreurs. On peut seulement spéculer sur les chances qu'il y a : ou bien que l'abcès soit opéré et la colonie vidée, ou bien que malencontreusement la colonie crève. ${ }^{32}$

26 A wider sense of the collapse of empire thus underpins Damas's reflections on the possible economic futures for French Guiana - including tourism and gold mining that might follow the closure of the bagne. Central to his argument is a consideration of how the imprint of the penal colony on those futures might be addressed, with the text concluding with an indication of the ruination that was likely to result: the French, he suggests, "risquent de voir en cette même Guyane, déjà agonisante, commencer l'effondrement de l'Empire français". ${ }^{33}$

27 At points in Retour de Guyane, Damas is tempted by counterfactual analyses as he confirms that "les immenses richesses de ce pays seraient demeurées même avec une population normale décidée à les exploiter", but his radical analysis focuses primarily on the socio-historical reality of the bagne and the implications of its postcolonial afterlives. Londres's humanitarian and reformist aim throughout his reportages - shared by other reporters of the interwar period - had been to explore social underworlds and 
to reveal social flaws. Damas envisaged something more overtly political and included a robust colonial critique that sought to highlight the incompetence of the French administration without nevertheless going so far as to undermine the rationale for empire: “Aussi bien dans l'intérêt du condamné lui-même, dans celui du contribuable métropolitain, que dans l'intérêt de la Guyane qu'elle paralyse, infeste, c'est une sinistre plaisanterie". ${ }^{34}$ Challenging the customarily racialized symbolism of colonial expansion that denigrates the perceived threat of the indigenous population, Damas presents the penal colony and the convicts themselves as an "infestation". ${ }^{35}$ In this way, Retour de Guyane belongs to the emerging Negritude movement, and as such contains clear blind spots regarding other histories of French Guiana, relating not least to the Amerindian genocide and the atrocious conditions in which most bagnards were living. Damas's conclusion, according to a logic of infiltration, is that bagne and colony have interpenetrated each other and become more and more dependent on one another, not in terms of the complementarity that nineteenth-century travellers such as Bouyer imagined might be possible, but to the extent that the removal of the penal system becomes "tout à fait secondaire" to another more fundamental question: "coloniser la Guyane ou l'évacuer". ${ }^{36}$

Following the abolition of transportation to the penal colony (in 1938) and the abolition of detention (in 1945), the bagne persisted in the French national imagination - not least in a series of popular expressions relating to it - as a lieu de mémoire associated with what Londres had called an "usine à malheur". ${ }^{37}$ The perpetuation and further ornamentation of this version of the sites of the penal colony was disseminated through narratives such as Henri Charriere's Papillon (1969). The cinematic version of Papillon, directed by James Franklin in 1973, ends with a vision of the penal colony gradually succumbing to postcolonial ruination and being overgrown by nature. These scenes are an iconic representation of the site's reduction - in the words of Patrick Chamoiseau - "au bagne de l'oubli". ${ }^{38}$ This amnesia regarding the Guianese bagne in its final years has recently been highlighted by Robert Badinter, who in a tribune in Le Monde in November 2017 described the treatment of prisoners under the Vichy administration as a "crime contre l'humanité" ${ }^{39}$ In the period before the colony joined the Free French in March 1943, a deliberately oppressive regime - associated with increased working hours, reduced rations of food, and lower standards of sanitation and health care - led to a mortality rate amongst the relégués of almost fifty percent. Without adopting the language of multi-directional memory, Badinter creates clear connections between the Caribbean penal colony and Nazi concentration camps, suggesting the existence in the context of what Michael Rothberg has dubbed "multidirectional memories". 40

In terms of understanding the penal colony today in the light of the past censorship represented by Damas's work and other forms of contemporary forgetting, Guyane: Traces-mémoires du bagne, a 1994 photo-essay by Patrick Chamoiseau and Rodolphe Hammadi, proposes one of the most sustained reflections on the challenges posed initially by Damas regarding the postcolonial meanings of the penal colony. Chamoiseau's reflection on the writing of colonial history shows how the site is not necessarily best approached as a place of colonial memory, i.e., as what Pierre Nora has called a lieu de mémoire, but is arguably better defined according to postcolonial tracesmémoires [memory-traces], a term drawing on both Derrida and Glissant to explain how the present continues to be linked to the past in the Americas. Entangled memories and itineraries can be seen in terms of what have been seen as nœuds de mémoire. ${ }^{41}$ The 
photo-essay has attracted legitimate criticism, not least because of its tendency to write out the population of Surinamese maroon origin who were forced to dwell in the Camp de la Transportation in the 1980s. However, Chamoiseau and Hammadi's book is based primarily on a critique of the formal memorial landscape of the territory, the ethnicized and predominantly white dimensions of which - according to the logic Damas described - are accentuated in official memorialization. The result is that: "ces édifices [...] ne témoignent pas des autres populations (Amérindiens, esclaves africains, immigrants hindous, syro-libanais, chinois...) qui, précipitées sur ces terres coloniales, ont dû trouver moyen d'abord de survivre, puis de vivre ensemble, jusqu'à produire une entité culturelle et identitaire originale". ${ }^{42}$ The goal of the Chamoiseau and Hammadi's project is, addressing these lacunae, to underline this same diversity of origins and experiences that the singularizing term bagnard tends to obscure, as well as the other populations and social groups with which convicts co-existed.

Chamoiseau refers to a body of representations of the bagne, but focuses instead an attempt to "percevoir ce que les Trace-mémoires nous murmurent". ${ }^{43}$ Hammadi's photographs on which the essayist comments indirectly are presented in the context of a new digressive approach: "non pas en visite mais en errance, non pas en flânerie mais en divagation". ${ }^{44}$ Towards the end of his text, Chamoiseau evokes the context of tourism, both dark and heritage-related, of the sites to which he refers and encourages the expulsion from these places of "les industriels du tourisme". ${ }^{45}$ Conservation will become a poetics, and curators will belong to "l'engeance des poètes". The author proposes a rejection of transformation of the site into a dark tourism destination, into a site of formal Republican memory, into a monument with guided trails: "Je ne peux - et ne veux pas - vous indiquer le sens de la visite, ni désigner la porte d'entrée, ou pire : vous dresser procès-verbal métrique des espaces et des murs" ${ }^{46}$ Chamoiseau proposes a rethinking of what Londres and Damas had suggested, namely a rendering of voice to a variety of bagnards, but unlike his predecessors, he does not then go on to impose his own story. He advocates instead renewed commitment to the ongoing task of challenging the censorship implicit in amnesia and recovering "des histoires dominées, des mémoires écrasées". ${ }^{47}$

\section{NOTES}

1. See Ann Laura Stoler, Duress: Imperial Durabilities in our Times, Durham, NC, Duke University Press, 2016; and Claire Anderson and Hamish Maxwell-Stewart, "Convict Labour and the Western Empires, 1415-1954", in The Routledge History of Western Empires, ed. by Robert Aldrich and Kirsten McKenzie, New York, Routledge, 2013, pp.102-17. For discussions of lieux de mémoire in a postcolonial context, see Etienne Achille, Charles Forsdick and Lydie Moudileno (eds) Postcolonial Realms of Memory: Sites and Symbols in Modern France, Liverpool, Liverpool University Press, 2020.

2. See the 30 May 1854 "loi sur l'exécution de la peine des travaux forcés". Available at: https:// criminocorpus.org/fr/reperes/legislation/textes-juridiques-lois-decre/textes-relatifs-a-ladeportati/acces-aux-textes/loi-du-30-mai-1854/ . 
3. On the deportation and transportation of Algerian conflicts to French Guiana, see Michel Pierre, « Les Algériens aux bagnes de Guyane », Histoire de la justice, 26.1 (2016), pp. 171-87.

4. On the réclusionnaires coloniaux, see Jean-Lucien Sanchez, "The French Empire, 1542-1976", in Claire Anderson (ed.), A Global History of Convicts and Penal Colonies, London: Bloomsbury, 2018, pp. 123-55 (p. 133).

5. See Jean Bernabé, Patrick Chamoiseau and Raphaël Confiant, Éloge de la créolité, Paris, Gallimard, 1989.

6. Comics have played a distinctive role in these processes. See Charles Forsdick, "Bande Dessinée and the Penal Imaginary: Graphic Constructions of the Carceral Archipelago", European Comic Art, 12.2 (2019), pp. 1-16.

7. On the bagne as lieu de mémoire, see Charles Forsdick, "Le Bagne", in Forsdick, Achille and Moudileno (eds), Postcolonial Realms of Memory, pp. 217-226.

8. Frédéric Bouyer, La Guyane française: notes et souvenirs d'un voyage exécuté en 1862-1863, Paris, Hachette, 1867, p.36.

9. Bouyer, La Guyane française, pp. 37-38.

10. Bouyer, La Guyane française, p. 265.

11. Bouyer, La Guyane française, p. 311.

12. Bouyer, La Guyane française, p. 207.

13. Damas, Retour de Guyane, pp. 50, 53.

14. Albert Londres, Au bagne, Paris, Le Serpent à plumes, 2002 [1923], p. 83. On the meaning of ailleurs in the French imaginary, see Albéric d'Hardivilliers, L'Écriture de l'ailleurs : petit propos sur la littérature nomade (Paris: Éditions Transboréal, 2013).

15. Londres, Au bagne, p. 31.

16. Londres, Au bagne, p. 73.

17. Londres, Au bagne, p. 89.

18. Londres, Au bagne, p. 202.

19. On the final years of the bagne, see Danielle Donet-Vincent, La Fin du bagne, Rennes, Éditions Ouest France, 1992.

20. On the biribi, see Dominique Kalifa, Biribi : les bagnes coloniaux de l'armée française, Paris, Perrin, 2009.

21. See Michel Pierre, "Imaginaire et mythologie des bagnes », Les Cahiers de la Justice, 1.1 (2020), pp. 61-76.

22. Many thanks to Sophie Fuggle for bringing this detail to my attention.

23. On Damas's mission on behalf of the museum, see Bart Miller, "Writing Wilderness and Civilization in Léon-Gontran Damas's Retour de Guyane and Black-Label”, Romance Studies, 29.3 (2011), pp. 186-97.

24. Emmanuel Lézy, « De la Guyane blanche à la Guyane noire, l'éternel retour de Léon Damas », in Antonella Emina (ed.), Léon-Gontran Damas. Cent ans en noir et blanc, Paris, CNRS, 2014, pp. $217-43$.

25. Bouyer, La Guyane française, p. 36.

26. Damas, Retour de Guyane, p. 48

27. Damas, Retour de Guyane, p. 126

28. René Maran, « Histoire des malheurs de la France équinoxale : Retour de Guyane ", La Dépêche de Toulouse, 6 April 1938, p. 5.

29. Damas, Retour de Guyane, p. 27.

30. Damas, Retour de Guyane, p. 86.

31. Damas, Retour de Guyane, pp. 49,50 . He seems to allude here to the creation of Inini, an inland territory of French Guiana administered separately from the rest of the colony between 1930 and 1946, and largely exploited though convict labour.

32. Damas, Retour de Guyane, p. 64. 
33. Damas, Retour de Guyane, p. 155.

34. Damas, Retour de Guyane, pp. 52, 54.

35. Damas, Retour de Guyane, p. 57.

36. Damas, Retour de Guyane, p. 64.

37. Londres, Au bagne, p. 31.

38. Patrick Chamoiseau and Rodolphe Hammadi, Guyane: traces-mémoires du bagne, Paris, Caisse nationale des monuments historiques et des sites, 1994, p. 18.

39. «Le bagne de Guyane : un crime contre l'humanité », Le Monde, 24 November 2017.

40. See Michael Rothberg, Multidirectional Memory: Remembering the Holocaust in the Age of Decolonization, Stanford, CA, Stanford University Press, 2009.

41. On this concept, see Michael Rothberg, Debarati Sanyal and Max Silverman (eds.), "Nœuds de mémoire: Multidirectional Memory in Postwar French and Francophone Culture", special issue, Yale French Studies, pp. 118-119 (2010).

42. Chamoiseau and Hammadi, Guyane, pp. 13-14.

43. Chamoiseau and Hammadi, Guyane, pp. 23, 24.

44. Chamoiseau and Hammadi, Guyane, p. 43.

45. Chamoiseau and Hammadi, Guyane, p. 45.

46. Chamoiseau and Hammadi, Guyane, p. 22.

47. Chamoiseau and Hammadi, Guyane, p. 16. This article draws on and develops in new directions research already presented in other fora. See Charles Forsdick, "The bagne as memory site: from colonial reportage to postcolonial traces-mémoires", in Eloise Brezault and Erica L. Johnson (eds), Memory as Colonial Capital, New York, Palgrave, 2017, pp. 79-97; and "Postcolonializing the bagne", French Studies, 72.2 (2018), pp. 237-55.

\section{ABSTRACTS}

The article focuses on the censorship of Léon-Gontran Damas's 1937 Retour de Guyane, a searing critique of French administration of this South American colony. The colonial authorities sought to ban Damas's book, allegedly purchasing and burning 1,000 copies of it (of a print-run, at the author's own expense, of only 1,500). In this book, Damas targets in particular the failure of the penal colony in the territory and suggests that the institution has impeded the development of the colony. The aim of the article is to read Damas' work in a wider corpus of texts devoted to the penal colony, most notably Frédéric Bouyer's travel narrative La Guyane française: notes et souvenirs d'un voyage exécuté en 1862-1863 (1867) and Albert Londres' Au bagne (1923). It suggests, however, that Retour de Guyane was a particularly incendiary text, mixing ethnographic report with anti-colonial essay, unpopular with the authorities in that it linked the collapse of the penal colony to the inevitable end of empire.

L'article se concentre sur la censure du livre de Léon-Gontran Damas, Retour de Guyane (1937), qui propose une critique acharnée de l'administration française de cette colonie sud-américaine. Les autorités coloniales ont cherché à interdire le livre de Damas, en achetant et en brûlant 1000 exemplaires (sur un tirage, aux frais de l'auteur, de seulement 1500 exemplaires). Damas vise en particulier l'échec du bagne sur le territoire et suggère que l'institution a entravé le développement de cette colonie. Le but de l'article est de lire l'œuvre de Damas dans un corpus plus large de textes consacrés au bagne, notamment le récit de voyage de Frédéric Bouyer La 
Guyane française: notes et souvenirs d'un voyage consacré en 1862-1863 (1867) et Au bagne d'Albert Londres (1923). L'article suggère, cependant, que Retour de Guyane était un texte particulièrement incendiaire, mélangeant rapport ethnographique et essai anticolonial, censuré par les autorités en ce qu'il liait l'effondrement du bagne à la fin désormais inévitable de l'empire colonial.

\section{AUTHOR}

\section{CHARLES FORSDICK}

Charles Forsdick is James Barrow Professor of French at the University of Liverpool. He has published on a range of subjects, including travel writing, colonial history, postcolonial and world literature, and the memorialisation of slavery. Recent books include The Black Jacobins Reader (Duke University Press, 2016), Toussaint Louverture: Black Jacobin in an Age of Revolution (Pluto, 2017) and Keywords for Travel Writing Studies (Anthem, 2019). Forsdick recently led an international project funded by the AHRC and LABEX on "'Dark Tourism' in Comparative Perspective: Sites of Suffering, Sites of Memory", exploring in particular questions of penal heritage and prison tourism.

Charles Forsdick est Professeur des Universités, titulaire de la chaire James Barrow en français à l'université de Liverpool. Ses publications portent sur une variété de sujets, parmi lesquels le récit de voyages, l'histoire coloniale, la littérature postcoloniale et mondiale ainsi que la mémorialisation de l'esclavage. Parmi ses ouvrages publiés récemment figurent The Black Jacobins Reader (Duke University Press, 2016), Toussaint Louverture: Black Jacobin in an Age of Revolution (Pluto, 2017) et Keywords for Travel Writing Studies (Anthem, 2019). Charles Forsdick a récemment été responsable d'un projet européen financé par l'AHRC et LABEX, intitulé "Dark Tourism' in Comparative Perspective: Sites of Suffering, Sites of Memory", qui explore en particulier les questions de tourisme carcéral et d'héritage pénal. 